\title{
PSIKOEDUKASI BAGI ORANGTUA YANG MEMILIKI ANAK BERKEBUTUHAN KHUSUS
}

\author{
Rina Mirza, Winida Marpaung, Yulinda Septiani Manurung \\ Fakultas Psikologi, Universitas Prima Indonesia \\ rinamirza.psi@gmail.com \\ winida.marpaung@gmail.com \\ lindayu109@hotmail.com
}

\begin{abstract}
Abstrack
Children with special needs are children who need special treatment due to developmental disorders and abnormalities experienced by children. For this reason, parents as people who are considered the closest to children are expected to understand the needs of children and have to learn a lot and explore what children need. Psychoeducation activities are one way that can be done to help parents understand their growth and recognize problems faced by children and how to overcome them. This psychoeducation activity is carried out in order to provide understanding for parents who have children with special needs. This activity is carried out for guardians of students whose children attend school at the UPT SLB-E Negeri Pembina at the North Sumatra Province. In carrying out this activity, it was conducted in four stages, namely (1) conducting interviews with children (if possible), parents and teachers related to children's behavior, (2) observing the behavior of children with special needs, (3) designing steps to change behavior that becomes a problem and (4) carry out psychoeducation and deliver the results to the parents of the child and the teacher. The results obtained are that parents increasingly understand how to recognize children's problems and analyze these problems and solve problems faced by their children.

Keywords: Psychoeducation, Parents, Children with Special Needs
\end{abstract}

\begin{abstract}
Abstrak
Anak berkebutuhan khusus merupakan anak yang memerlukan penanganan khusus karena adanya gangguan perkembangan dan kelainan yang dialami anak. Untuk itu, orangtua sebagai orang yang dianggap paling dekat dengan anak diharapkan memahami kebutuhan anak dan harus banyak belajar serta menggali ilmu mengenai apa yang dibutuhkan anak. Kegiatan Psikoedukasi adalah salah satu cara yang bisa dilakukan untuk membantu orangtua dalam memahami tumbuh kembangnya serta mengenali masalah yang dihadapi anak dan cara mengatasinya. Kegiatan psikoedukasi ini dilaksanakan dalam rangka memberikan pemahaman bagi orangtua yang memiliki anak berkebutuhan khusus. Kegiatan psikoedukasi ini diberikan kepada wali murid yang anaknya bersekolah di UPT SLB-E Negeri Pembina Tingkat Provinsi Sumatera Utara. Dalam pelaksanaan kegiatan ini, dilakukan dengan empat tahapan yakni (1) melakukan wawancara terhadap anak (jika memungkinkan), orangtua dan guru terkait perilaku anak, (2) melakukan observasi terhadap perilaku anak berkebutuhan khusus, (3) mendesain langkah yang akan dilakukan untuk merubah perilaku yang menjadi masalah serta (4) melaksanakan psikoedukasi dan menyampaikan hasilnya kepada orang tua si anak maupun guru. Hasil yang diperoleh bahwa orangtua semakin memahami bagaimana cara mengenali masalah anak dan menganalisa masalah tersebut serta menyelesaikan masalah yang dihadapi anaknya.
\end{abstract}


Kata kunci: Psikoedukasi, Orangtua, Anak Berkebutuhan Khusus

\section{PENDAHULUAN}

Setiap anak yang lahir dari rahim ibunya, pastinya memberikan konsekuensi tanggung jawab baru pula kepada kedua orangtuanya. Selain itu, orangtua pastinya memiliki segudang harapan kepada anaknya agar anaknya menjadi anak yang dapat membahagiakan kedua orangtuanya. Seorang anak juga sangat membutuhkan perhatian yang cukup dari kedua orangtuanya. Menurut Hariwijaya dan Sukaca (2009), secara teoritis anak-anak akan berkembang secara optimal apabila mendapatkan perhatian yang penuh dari orangtua yang memahami perkembangan anak dan memiliki waktu yang cukup.

Perhatian yang cukup sangatlah dibutuhkan oleh semua anak, termasuk anak berkebutuhan khusus juga sangat membutuhkan perhatian dari kedua orangtuanya. Menurut Winarsih, dkk (2013), anak berkebutuhan khusus adalah anak yang mengalami keterbatasan atau keluarbiasaan, baik secara fisik, mental-intelektual, sosial maupun emosional, yang berpengaruh secara signifikan dalam proses pertumbuhan atau perkembangannya dibandingkan dengan anak lainnya yang seusia dengannya. Desiningrum (2016) menambahkan bahwa anak berkebutuhan khusus merupakan anak yang memerlukan penanganan khusus karena adanya gangguan perkembangan dan kelainan yang dialami anak.

Lebih lanjut, Desiningrum (2016) mengklasifikasikan anak berkebutuhan khusus dalam beberapa bagian, diantaranya:

1. Anak dan kaitannya dengan kemampuan intelektual, meliputi:

a. CIBI/ cerdas istimewa berbakat istimewa, yakni anak mempunyai bakat/ kelebihan dalam hal kecerdasan, kreativitas, tanggung jawab terhadap tugas yang tinggi dibandingkan anak seusianya).

b. Kesulitan belajar khusus, yakni berkaitan dengan membaca, menulis, berhitung.

c. Slow learner/ lamban belajar/ MR (memiliki IQ 70-90).

d. Tuna grahita/ Down Sindrom (keterbelakangan mental, IQ jauh dibawah rata-rata, sehingga kesulitan dalam tugas akademik, komunikasi maupun sosial).

2. Anak dengan gangguan emosi, sosial dan perilaku, meliputi: 
a. Autisme, yakni gangguan perkembangan yang disebabkan karena adanya gangguan pada sistem syaraf pusat yang mengakibatkan gangguan dalam interaksi sosial, komunikasi dan perilaku.

b. ADHD (attention deficit hyperactivity disorder), yakni gangguan pemusatan perhatian yang disertai dengan hiperaktif

c. Anxiety, yakni perasaan tidak nyaman, yang didominasi dengan rasa takut, khawatir, gelisah yg tidak terkendali.

d. Indigo, yakni individu yang sejak lahir memiliki kelebihan khusus yang tidak dimiliki orang lain pada umumnya.

e. Conduct disorder, Tuna laras, yakni kesulitan dalam penyesuaian diri dan bertingkah laku tidak sesuai dengan norma yang berlaku.

3. Anak dengan gangguan fisik, meliputi:

a. Tuna netra, yakni indera penglihatan tidak berfungsi secara normal

b. Tuna rungu, yakni hilang sebagian/ keseluruhan daya pendengarannya sehingga mempengaruhi komunikasi verbalnya.

c. Tuna daksa, yakni mengalami kelainan/ cacat yang menetap pada alat gerak (tulang, sendi dan otot)

d. Celebral palsy (bagian dari tuna daksa) yakni kelainan gerak, sikap, bentuk tubuh, gangguan koordinasi dan bisa disertai dengan gangguan psikologis dan sensoris yang disebabkan oleh kerusakan pada masa perkembangan otak.

Untuk anak berkebutuhan khusus, tidak hanya perhatian saja yang dibutuhkan namun peran orang tua sangat diharapkan guna memantau pertumbuhan dan perkembangan anak tersebut, salah satu perannya adalah mendukung dan memahami masalah yang dihadapi anak berkebutuhan khusus tersebut. Tidak sedikit orang tua yang merasa beban dengan kondisi anaknya yang memiliki keterbatasan sehingga orangtua juga harus diberi pemahaman cara mendidik anak berkebutuhan khsuus. Salah satu caranya adalah memberikan psikoedukasi.

Menurut Griffith (dalam Walsh, 2010) psikoedukasi adalah suatu intervensi yang dilakukan pada individu, keluarga dan kelompok yang focus pada mendidik partisipasinya mengenai tantangan signifikan dalam hidup, membantu partisipan mengembangkan sumbersumber dukungan, dan dukungan sosial dalam menghadapi tantangan tersebut dan mengembangkan keterampilan coping untuk menghadapi tantangan tersebut. 
Melihat pentingnya psikoedukasi ini, maka dilaksanakanlah kegiatan dalam rangka memberikan psikoedukasi bagi orangtua yang memiliki anak berkebutuhan khusus.

\section{METODE PELAKSANAAN}

Pelaksanaan kegiatan psikoedukasi ini dilakukan pada tanggal 23 April - 25 April 2018 bagi wali murid yang anaknya bersekolah di UPT SLB-E Negeri Pembina Tingkat Provinsi Sumatera Utara. Kegiatan pengabdian masyarakat dalam rangka memberikan psikoedukasi bagi orangtua yang memiliki anak berkebutuhan khusus ini dilakukan dalam beberapa tahapan, yaitu: (1) Melakukan wawancara terhadap anak (jika memungkinkan), orangtua dan guru terkait perilaku anak, (2) Melakukan observasi terhadap perilaku anak berkebutuhan khusus, (3) Mendesain langkah yang akan dilakukan untuk merubah perilaku yang menjadi masalah, (4) Melaksanakan psikoedukasi dan menyampaikan hasilnya kepada orang tua si anak maupun guru.

Pada tahap pertama yakni melakukan wawancara terhadap anak (jika memungkinkan), orangtua dan guru terkait perilaku anak. Wawancara dilakukan untuk memperoleh data lengkap terkait masalah yang dialami anak maupun orangtua dalam mengatasi masalah perilaku anak. Wawancara ini dilakukan secara individual karena ingin menggali masalah yang dihadapi anak/ orangtua/ guru terkait masalah yang dihadapinya.

Tahap kedua dilanjutkan dengan melakukan observasi terhadap perilaku anak berkebutuhan khusus. Observasi ini dilakukan terkait perilaku anak berkebutuhan khusus dan bagaimana interaksi antara orangtua dan anak serta hal lain yang berkaitan dengan masalah yang dihadapi anak. Observasi ini berguna untuk mendapatkan informasi tambahan terkait masalah yang dihadapi anak/ orangtua/ guru.

Setelah diperoleh data dari hasil wawancara dan observasi, maka tahap ketiga dilanjutkan dengan mendesain langkah yang akan dilakukan untuk merubah perilaku yang menjadi masalah. Tahap terakhir yakni tahap keempat dilanjutkan dengan psikoedukasi dan menyampaikan hasil kepada orang tua si anak maupun guru.

Berikut ini merupakan gambar-gambar yang diperoleh selama pelaksanaan program pengabdian masyarakat dalam rangka memberikan psikoedukasi bagi orangtua yang memiliki anak berkebutuhan khusus di UPT SLB-E Negeri Pembina Tingkat Provinsi Sumatera Utara. 

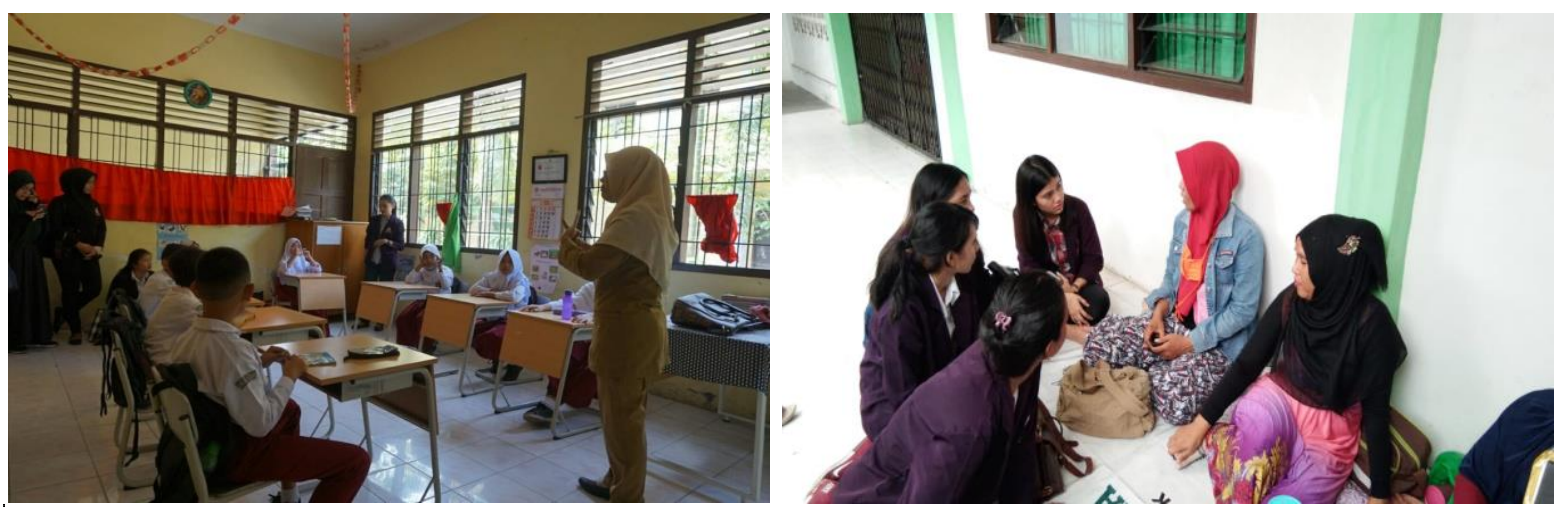

Gambar 1. Pelaksanaan Observasi

Gambar 2. Pelaksanaan Psikoedukasi
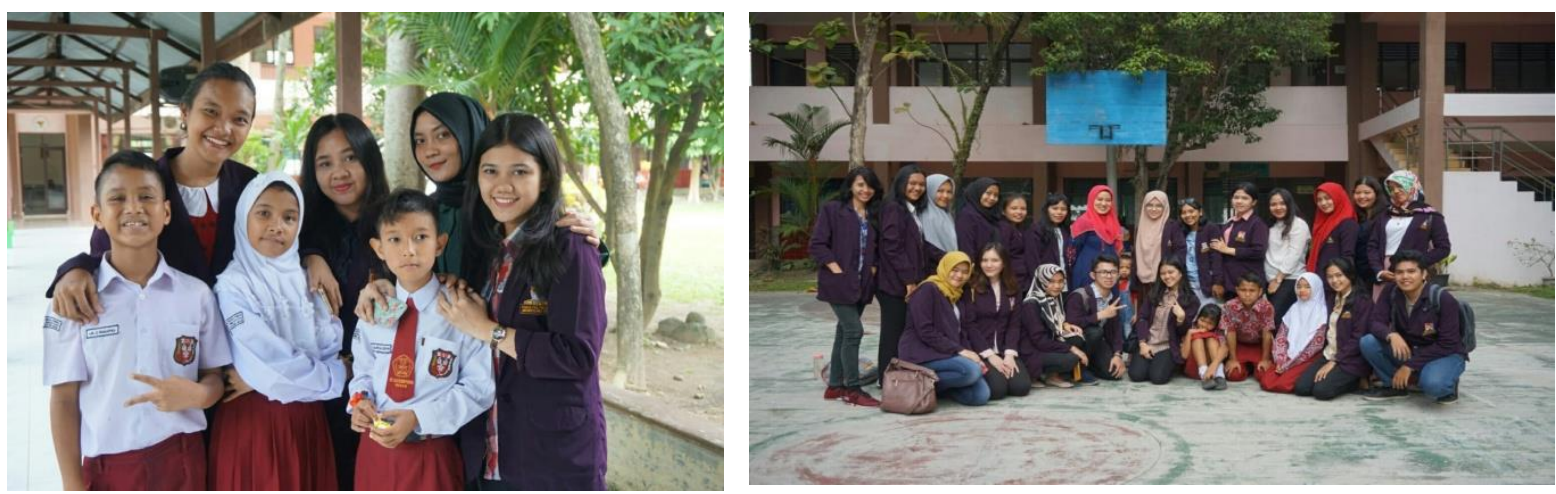

Gambar 3.

Gambar 4.

Foto TIM bersama Siswa

Foto TIM setelah pelaksanaan Kegiatan

\section{HASIL DAN PEMBAHASAN}

Hasil dari kegiatan pengabdian masyarakat dalam rangka memberikan psikoedukasi bagi orangtua yang memiliki anak berkebutuhan khusus ini adalah:

1. Pencapaian tujuan pengabdian kepada masyarakat yang membutuhkan, dalam hal ini kepada orangtua yang memiliki anak berkebutuhan khsuus.

2. Pencapaian tujuan bahwa orangtua semakin memahami akan masalah dan kondisi anaknya yang merupakan anak berkebutuhan khusus. Disamping itu, orangtua semakin memahami bagaimana cara mengenali masalah anak dan menganalisa masalah tersebut serta menyelesaikan masalah yang dihadapi anaknya.

Sebagaimana yang telah diuraikan sebelumnya bahwa psikoedukasi ini merupakan salah satu intervensi dilakukan pada individu, keluarga dan kelompok yang fokus pada 
mendidik partisipasinya mengenai tantangan signifikan dalam hidup, membantu partisipan mengembangkan sumber-sumber dukungan, dan dukungan sosial dalam menghadapi tantangan tersebut dan mengembangkan keterampilan coping untuk menghadapi tantangan tersebut (Griffith, dalam Walsh, 2010).

Kaitannya dengan kegiatan pengabdian masayarakat ini adalah, dengan penerapan psikoedukasi ini dapat membantu orangtua menemukan masalah yang mereka hadapi terkait anaknya. Selain itu, memberi pemahaman bagi orang tua terkait bagaimana sikap orangtua terhadap anaknya. Menurut Somantri (2006) sikap orangtua yang baik untuk perkembangan kepribadian anak adalah sikap mengerti, mencintai dan menaruh perhatian pada anak sebagai individu. Orangtua yang kurang hangat atau menolak, sangat berpengaruh terhadap perkembangan kepribadian anak.

\section{SIMPULAN}

Berdasarkan hasil psikoedukasi yang diberikan kepada orangtua yang memiliki anak berkebutuhan khusus ini, disimpulkan bahwa banyak orangtua yang mengalami kesulitan dalam menghadapi perilaku anak mereka yang mengalami keterbatasan. Hal ini diperburuk dari lingkungan sekitar mereka yang kurang mendukung. Dengan adanya psikoedukasi ini, memberi gambaran pada orangtua bagaimana cara mendidik anak berkebutuhan khusus dan bagaimana mereka harus bersikap terhadap perilaku oranglain yang kurang menerima keberadaan anak mereka.

\section{DAFTAR PUSTAKA}

Hariwijaya, M, \& Sukaca, B.E. 2009. PAUD Melejitkan Potensi Anak Dengan Pendidikan Sejak Dini. Yogyakarta: Mahadhika Publishing.

Somantri, T.S. 2006. Psikologi Anak Luar Biasa. Bandung: PT. Refika Aditama.

Walsh, J. 2010. Psychoeducation In Mental Health. Chicago: Lyceum Books, inc.

Winarsih, S., Jamal's, H., asiah, A., Idris, F.H., Adnan, E., Prasojo, B., Tan, I., Masyhuri, A.A., Syafrizal., Madjid, S., Hasnul, N., Riyanto, A., Bunawan, L., Rukiyah, S.C \& Sembada, I.K. 2013. Panduan Penanganan Anak Berkebutuhan Khusus Bagi Pendamping (Orangtua, Keluarga dan Masyarakat). Jakarta: Kementerian Pemberdayaan Perempuan dan Perlindungan Anak. Diakses pada tanggal 18 Maret 2019, dari https://www.kemenpppa.go.id/lib/uploads/list/b3401-panduan-penangananabk-bagi-pendamping-_orang-tua-keluarga-dan-masyarakat.pdf. 